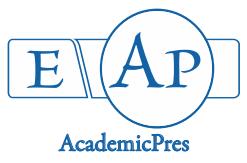

Adhikari BS and Kumar R (2020)

Notulae Scientia Biologicae 12(4):901-919

DOI: $10.15835 / 12410716$

Research Article

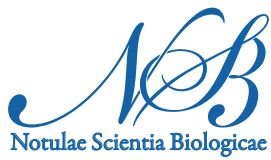

\title{
Effect of snowmelt regime on phenology of herbaceous species at and around treeline in Western Himalaya, India
}

\author{
Bhupendra S. ADHIKARI*, Rahul KUMAR \\ Wildlife Institute of India, Department of Habitat Ecology, Chandrabani, Dehradun 248007, Uttarakhand, \\ India; adhikaribs@wii.gov.in (*corresponding author); rkbrks@wii.gov.in
}

\begin{abstract}
The present study attempts to investigate the phenological changes of herbaceous plant species in early snowmelt microsite and late snowmelt microsite in treeline ecotone (3200-3300 $\mathrm{m}$ asl) at Tungnath, western Himalaya. Four sites, each with two microsites (early snowmelt: ES and late snowmelt: $L S$ ) were selected and within each microsite, 3 quadrats ( $1 \mathrm{x} 1 \mathrm{~m}$ each) were permanently laid and studied for phenology. Eighty-six species were recorded, of which the proportion of perennial forbs, hemicryptophytes and natives was 90,84 and $70 \%$, respectively. The early phenophase was noticed in the majority of species in ES microsite than that of LS microsite and the timing of different phenophases varied among microsites. The vegetative phase peaked July (75.6\%), while flowering, fruiting and seed maturation phases peaked in August (72.1\% and $23.3 \%$, respectively) and $71 \%$ species attained the senescence during September. This indicates that species might adapt to the different adaptation to a warming climate. Immediately after the snowmelt 10 species were observed in flowering, while 11 species were in the bud development phase. Comparing 13 common species of the present study with those of past in same or similar study areas indicates that timing and duration of vegetative and flowering phenophase (77\% and 69\%, respectively) have advanced and lengthened, while fruiting and seed maturation have shortened. Furthermore, phenophase initiation has advanced for flowering (69\% species), fruiting ( $46 \%$ species) and senescence (38\% species) phases. It seems that the early snowmelt influences spring phenology of herb species on the microsite level and may continue to influence the overall phenology of species for the whole growing season in timberline.
\end{abstract}

Keywords: climate change; ecotone; phenophase; snowmelt; treeline

\section{Introduction}

Above a certain elevation, due to 'physiognomic discontinuum' (Singh, 2018), there is a transition from trees to herbaceous meadows which can be seen as an imaginary line separating meadow from the forest through short stature tree patches/krummholz (Körner, 2012a). This transition is driven by temperature decline due to increasing elevation (Mayor et al., 2017) and represents an ecotone of vast biodiversity importance (Callaghan et al., 2002; Singh, 2018) as vascular plants decrease with an altitudinal gradient (Mohapatra, 2015) leading to increase in endemic (Dhar, 2000) and native species. But due to anthropogenic climate change, especially warming, these ecotones are experiencing ecological changes (Gobiet, 2014) especially warminginduced biodiversity changes (Pauli et al., 2007; Gottfried et al., 2012; Wipf et al., 2013) and species redistribution (Lenoir et al., 2008; Chen et al., 2011; Grytnes et al., 2014; Pauli et al., 2007, 2012) affecting 
richness (Steinbauer et al., 2018), growth and phenology (Liu et al., 2014; Anadon-Rosell et al., 2014) of species on or near mountain summits which may result in group extinction of range-restricted species (Parmesan, 2006). Furthermore, warming promotes tree growth which may push treeline elevation (Grabherr et al., 1994; Grace et al., 2002; Walther et al., 2005; Peñuelas et al., 2007; Schickhoff et al., 2015) thus affecting snow cover regime and microclimate of species and their interactions (Wielgolaski et al., 2017). A lot of studies have pointed out the potential impact of warming on treeline ecotones (Grace et al., 2002; Camarero and Gutierrez 2002; Dolezal and Srutek, 2002; Baker and Moseley, 2007; Batllori et al., 2009a; Batllori et al., 2009b; Kaarlejarvi et al., 2012; Cudlin et al., 2017; Kambo and Danby, 2017) but they in general deal with either tree density, seedling regeneration/dispersal or tree phenology but have neglected herbaceous vegetation, especially phenology, in treeline ecotones.

Cold climate species (treeline and alpine) have developed through selection filters of resisting cold as a primary evolutionary filter while phenology comes a close second (Körner, 2016a) as it controls initiation and termination of growth which protects vulnerable tissues from freezing temperature (Körner and Basler, 2010; Körner et al., 2016). Small plant stature in treeline is an adaptation for warmer growing season as they generate their microclimate through heat exchange, also known as facilitation (Aulitzky, 1961; Körner, 2012b; Körner, 2016b) especially true for herbaceous species, which make them susceptible to frost. Global warming has affected seasonal life history i.e. phenology of many plant species (Parmesan, 2006), most of which is believed to have advanced for treeline in general, but this shift in initiation and duration is not unidirectional and shifts depend upon species response (Parmesan, 2007; Thackeray et al., 2010). Many studies have shown positive growth response to warming (Arft et al., 1999; Campioli et al., 2012) while other show a lag or inconsistent response in plant growth over time (Elmendorf, 2012). This leads to a decrease in temporal overlap causing phenological mismatch (Kudo and Ida, 2013) affecting the reproduction and survival of species (MillerRushing et al., 2010). But under present warming false initiation of growth season due to early thawing of snow (especially in mountain treelines) may cause damage to tissues leading to the death of plants. This is especially true for herbaceous vegetation under tree canopy in treeline ecotones. Since herbs have adapted themselves for the cold climate they need to grow and reproduce undergrowth restricting temperature this warming may not give them ample time to adapt to microclimate change. Since phenology is strongly dependent on temperature (Walther, 2003) it is the simplest way to track changes happening due to the warming environment, especially on a regional scale.

Besides temperature snow is another important factor controlling microclimate and plant growth in treeline ecotones (Wipf and Rixen, 2010). It acts as an insulator protecting herbaceous plants (Sturm et al., 1997) while its duration and extend determine the occurrence of plant communities (Evans et al., 1989; Walker et al., 1993; Odland and Munkejord, 2008) and beginning of growth season through snowmelt (Jones et al., 2001; Pomeroy and Brun, 2001; Inouye and Wielgolaski, 2003; Körner, 2003). But due to warming, it is fastest-changing environmental factor globally (Laternser and Schneebeli, 2003; Lopez-Moreno, 2005; Mote et al., 2005; Dyer \& Mote, 2006; Barnett et al., 2008; Clow, 2010; IPCC, 2013; Mote et al., 2018), which leads to early snowmelt resulting in potentially warmer and longer growing season affecting community composition, richness (Körner, 2003; le Roux et al., 2013) and phenology (Smith et al., 2012), and may increase frost damage because of early dehardning (Kimmins and Lavender, 1992; Cumming and Burton, 1996; Inouye, 2000; Gorsuch and Oberbauer 2002). This changing regional climate is already affecting treeline ecotones, rich in high-value medicinal, aromatic and threatened plants, and further pressurized by anthropogenic disturbances (Winkler et al., 2018) resulting in altering of functional attributes of alpine plants which lead to increased productivity initially at cost of nutrient reserve depletion in long term (Wookey et al., 1993; Chapin and Shaver, 1996) affecting nutrient cycling and net primary productivity (Rathcke and Lacey, 1985; Eviner and Chapin, 2003).

Somehow there is a lack of data on herbaceous phenological responses to a warming climate, especially missing in context to Himalayan treeline ecotones. Although, many studies can be found on herbaceous phenology (Sundriyal et al., 1987; Negi et al., 1992; Nautiyal et al., 2001; Bijalwan et al., 2013), nearly all of 
them focused on phenology in alpine meadows. This is also true for the studies on the relationship between snowmelt and phenology due to remoteness and difficult terrain leading to inaccessibility. Therefore, the present study is an attempt to investigate the relationship between snowmelt and phonological attributes of herbaceous species at timberline ecotone in western Himalaya, which may act as baseline information for future studies.

\section{Materials and Methods}

\section{Studyarea}

The study area is located at Tungnath lying in the upper catchment of Alaknanda (one of the two tributaries of river Ganga) and Mandakini rivers of Uttarakhand, a western Himalayan state of India (Figure 1). The year is divisible into four seasons viz., short summer (May to June), monsoon (July to mid-September), autumn (mid-September to October), and long winter (November-April). The period with snow cover is of about 4-5 months (December-April) in general and snowmelts during April-May between 3200-3300 m. Adhikari et al. (2012) reported the mean monthly temperature ranged between -8.9 in January and $+25.6^{\circ} \mathrm{C}$ in May, with an average of $6.7 \pm 0.7^{\circ} \mathrm{C}$ during 2008-2010 and mean temperature of the warmest month July was $12.6 \pm 1.2^{\circ} \mathrm{C}$ at timberline ecotone $(3300 \mathrm{~m})$ in Tungnath. Annual precipitation was $2410.5 \pm 432.2 \mathrm{~mm}$, of which $89.5 \%$ was recorded during June-September ( 4 months).

The understory vegetation mainly consists of forbs, grasses and sedges along with Rhododendron campanulatum krummholz at treeline. Over last 36 years (1981-2017) following changes were discernible for Tungnath region over time from the past climatic data obtained from NASA (http://cosweb.larc.nasa.gov./\#dataaccess): relative humidity $\left(\mathrm{r}^{2}=0.289, \mathrm{P}<0.05\right)$, dew/frost point $\left(\mathrm{r}^{2}=\right.$ $0.403, \mathrm{P}<0.01)$, minimum $\left(\mathrm{r}^{2}=0.298, \mathrm{P}<0.05\right)$ and maximum temperatures $\left(\mathrm{r}^{2}=0.007, \mathrm{P}<0.001\right)$ have increased. However, during pre-monsoon (March to May), which is dry and windy, relative humidity $\left(\mathrm{r}^{2}=\right.$ $0.226, \mathrm{P}<0.05)$ and dew/frost point $\left(\mathrm{r}^{2}=0.129, \mathrm{P}<0.05\right)$ have decreased, while wind speed $\left(\mathrm{r}^{2}=0.060, \mathrm{P}<\right.$ $0.001)$, maximum $\left(\mathrm{r}^{2}=0.145, \mathrm{P}<0.05\right)$ and minimum temperatures $\left(\mathrm{r}^{2}=0.061, \mathrm{P}<0.001\right)$ have increased. The decline in pre-monsoon humidity could be due to the rise in temperature and an increase in wind speed. The annual rainfall has increased over time during the 36-year period $\left(\mathrm{r}^{2}=0.324, \mathrm{P}<0.01\right.$; Adhikari et al., 2018). 


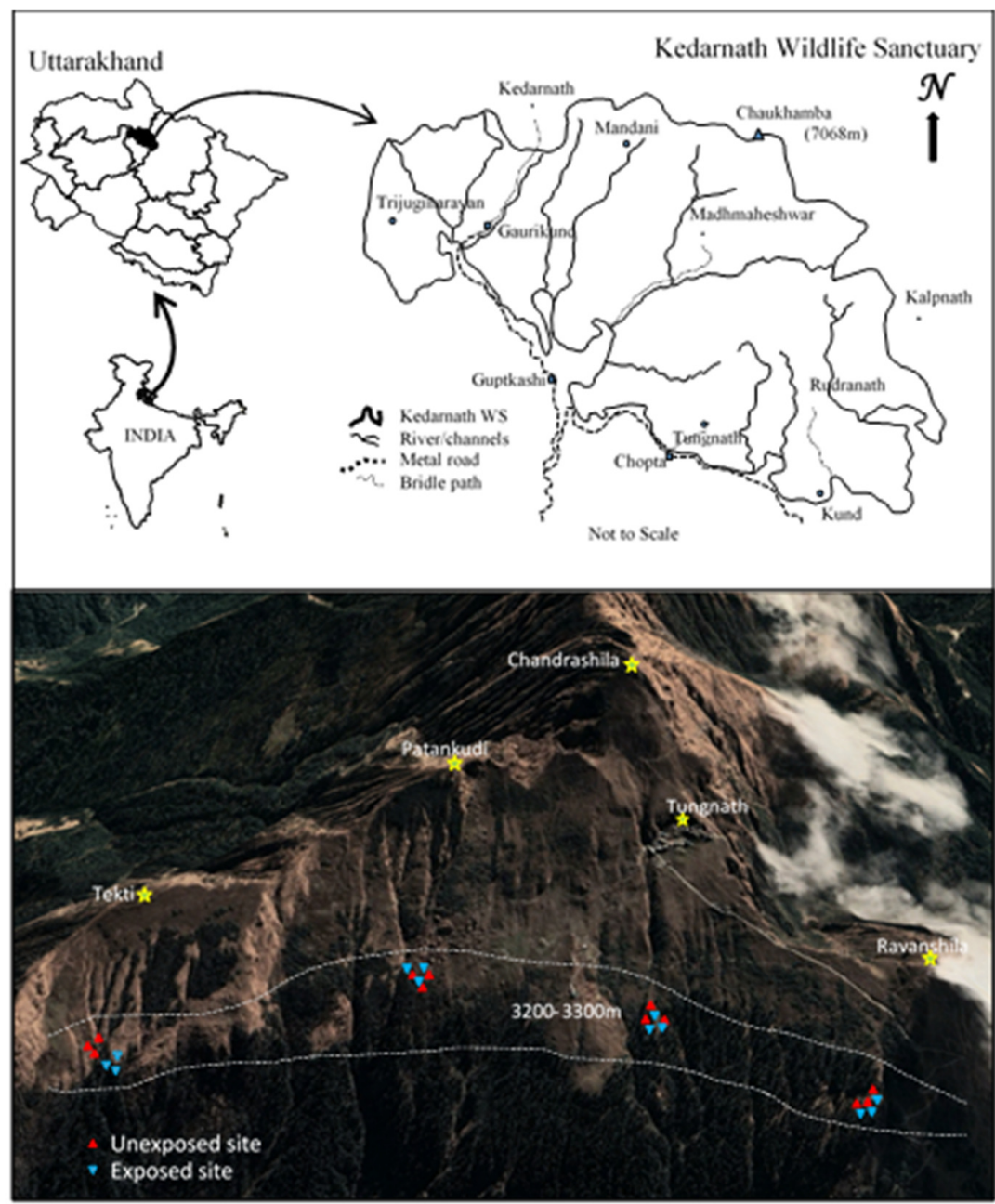

Figure 1. Map of the study area with the location of plots in early and late snowmelt microsites

\section{Methods}

At Tungnath, the treeline summit is almost ca. $2 \mathrm{~km}$ long predominated by Abies spectabilis and Quercus semecarpifolia forests with Rhododendron krummholz. To determine the effect of spring snowmelt on plant species 4 study plots of 20x20m were selected at the base of 4 summits (Ravanshila, Chandrashila, Patankudi and Jhabra) between 3200-3300 m asl. The study plots were further divided into two microsites composed of exposed areas on with ridges with no canopy cover and early snowmelt (ES), and unexposed areas on troughs with canopy cover and late snowmelt (LS). Within study plots 6 random quadrats $(1 \times 1 \mathrm{~m}$ each) were permanently laid with a distance of $5-7 \mathrm{~m}$ (3 each in ES microsites and LS microsites) within the selected plot to study phenology of plant species. The exposed microsite (hereby referred to as ES) had a convex surface where snowmelt began earlier than unexposed microsite (hereby referred to as LS), which were with concave surface causing snow deposition resulting in a longer stay of snow due to presence of krummholz and snowdrift due to high winds.

The permanent plots were used to make visual phenological observations on a monthly interval to monitor all species present. Data were recorded for different phenological stages of species present as per the Biologische Bundesanstalt Bundessortenamt und CHemische Industrie scale (BBCH; Hess et al., 1997). The $\mathrm{BBCH}$ scale was chosen as it provides uniform coding primarily to phenologial criteria instead of differentiating analogous stages. Furthermore, it is a detailed observation key allowing the recording of the frequency distribution of phenophase of individuals on sampling date, so the presence is not required at the 
beginning of phenophase (Cornelius et al., 2013). In BBCH scale entire development cycle of plant species can be divided into 10 principal stages (0-9, Table1) which are further subdivided into 10 secondary stages (0-9) corresponding to intermediate stages linked to the principal stage. It is difficult to pinpoint in alpine herb species which secondary stage is dominant at a particular time as some species, in general, may also skip some primary stages depending on microclimate. Therefore, we combined different primary phenophases into 4 major categories (Table 1).

The study was focused to record all major phenophases with corresponding principal stages for all species present in permanent plots for growing season from May to October, 2017. All the individuals of species were observed in permanent plots and although multiple phenophases were observed at the same time, the existence of a particular phenophase was considered if $5 \%$ of individuals showed that phenophase, to avoid overlapping and get results.

Table 1. Different growth phases and description as per the BBCH scale (modified after Hess et al., 1997)

\begin{tabular}{|c|c|c|c|}
\hline Growth phase & Code & Code names & Code description \\
\hline \multirow{4}{*}{ Vegetative phase } & 0 & $\begin{array}{c}\text { Germination/sprouting/bud } \\
\text { development }\end{array}$ & From dry seed till leaf breaks the soil \\
\hline & 1 & Leaf development (main shoot) & $\begin{array}{l}\text { The first leaf to nine or more leaves/whorls } \\
\text { development }\end{array}$ \\
\hline & 2 & $\begin{array}{l}\text { Formation of side } \\
\text { shoots/tillering }\end{array}$ & $\begin{array}{l}\text { First side shoot/tiller to nine or more } \\
\text { shoot/tiller visible }\end{array}$ \\
\hline & 3 & $\begin{array}{c}\text { Stem elongation/shoot } \\
\text { development (Main shoot) }\end{array}$ & $\begin{array}{c}\text { Beginning of stem elongation to nine or } \\
\text { more nodes }\end{array}$ \\
\hline \multirow{3}{*}{ Reproductive Phase } & 4 & $\begin{array}{l}\text { Vegetative propagation/ booting } \\
\text { (Main shoot) }\end{array}$ & $\begin{array}{l}\text { Development of propagation organ to first } \\
\text { awl visible }\end{array}$ \\
\hline & 5 & $\begin{array}{l}\text { Inflorescence emergence (Main } \\
\text { shoot)/heading }\end{array}$ & $\begin{array}{l}\text { Inflorescence/ flower bud visible to full } \\
\text { emergence }\end{array}$ \\
\hline & 6 & Flowering (Main shoot) & $\begin{array}{l}\text { First flower till the end of flowering till fruit } \\
\text { set visible }\end{array}$ \\
\hline \multirow{2}{*}{$\begin{array}{c}\text { Fruit/Seed } \\
\text { development and } \\
\text { Maturation }\end{array}$} & 7 & Development of fruit & $\begin{array}{l}\text { Fruit begins to develop until maturity for } \\
\text { species and location }\end{array}$ \\
\hline & 8 & $\begin{array}{c}\text { Ripening and maturity of fruit or } \\
\text { seed }\end{array}$ & $\begin{array}{l}\text { Beginning of ripening o fruit colouration } \\
\text { till fully ripe }\end{array}$ \\
\hline Senescence & 9 & \multicolumn{2}{|c|}{ Plant dead or plant resting or dormant } \\
\hline
\end{tabular}

\section{Results}

The plant growth period was about 6 months from mid-April to mid-October. In total 86 species were recorded during the study period of which 56 species were common in both ES and LS microsites. Of the total species, 30\% each were erect leafy and semi basal growth forms and 35\% short basal growth forms, whereas 4 species each were represented by climber, tussock, shrub and dwarf shrub.

Of the total 56 common species, 20 species namely Anaphalis nepalensis, Anemone rivularis, Bistorta affinis, Bistorta amplexicaulis, Caltha palustris, Carex setosa, Circea alpina, Fragaria nubicola, Kobrasia dutheii, Lysimachia prolifera, Nepeta govaniana, Oxygraphis polypetala, Polygonum filicaule, Polygonum vaccinifolium, Potentilla atrosanguinea, Potentilla polyphylla, Prunella vulgaris, Ranunculus hirtellus, Selinum vaginatumand Trachydium roylei contributed greatly to density in both ES and LS microsites(BS Adhikari; unpubl. data). The species such as Anemone rivularis, Bistorta affinis, Circea alpinaand Potentilla atrosanguinea dominated inLS microsite and Anaphalis nepalensis,Kobrasia dutheii, Nepeta govaniana, Oxygraphis polypetala and Selinum vaginatum dominated in ES microsite. Across months Fragaria nubicola, Rannunculus hirtellus, Polygonum filicaule, Bistorta amplexicaulis were dominated in LS microsite, while 
Rannunculus hirtellus, Carex setosa, Trachydium royelie, Oxygraphis polypetala, Fragaria nubicola and Anaphalis nepalensis were the dominant species in ES microsite (BS Adhikari; unpubl. data).

As the study is primarily focused on the phenological changes of herbaceous species as per growth forms viz. erect leafy, semi basal, short basal and other growth forms at and around timberline, the results are as follows:

\section{Erect leafy growth form}

Sixteen erect leafy species were common in both ES and LS microsites, of which Bistorta affinis, $B$. amplexicaulis, Pimpinella diversifolia, Prunella vulgaris, Rannunculus hirtellus, Swertia ciliata, S. Speciosa germinated in May, Buplurum longicaule, Circea alpina, Imapatiens scrabida, Myriactis walichii, Polygonum polystachium, Stachys melissifolia, Swertia cordata, Veronica canain June and Epilobium royleanumin July. In Bistorta affinis and Pimpinella germination observed in May in LS microsite, while in June and July, respectively in ES microsite. $S$ wertia ciliata germinated in ES microsite in May, but it did not show vegetative phase in LS microsite. Swertia speciosa germinated in both ES and LS microsites, but carried its lifecycle in LS microsite only. Circea alpina and Imapatiens scrabidagerminated during June in LS microsite, while Buplurum longicaule, Polygonum polystachium, Stachys melissifolia and Swertia cordata germinated in ES microsite. Flowering started in early May for erect leafy species. Rannunculus showed two different flowering periods, beginning from early and mid-May and continued till the end of June in both ES and LS microsites, respectively, while the vegetative phase returned in June end in ES microsite. Rannunculus again flowered in mid-August in both ES and LS microsites. Bistorta affinis and B. amplexicaulis flowered early in LS microsite in June and July, respectively, while Imapatiens scrabida and Pimpinellaflowered during July in LS microsite. Buplurum longicaule and Veronica cana flowered in June, while Prunella, Swertiaciliataand Swertia cordata during July in ES microsite. Swertia ciliata only showed flowering phenophase, while Epilobium royleanum showed only vegetative and flowering phenophase in LS microsite. Polygonum polystachium flowered in early August in ES microsite and mid-August in LS microsite. Circea alpina, Stachys melissifolia and Myriactis walichii entered the reproductive phase in mid-July, early and mid-August, respectively in both ES and LS microsites. Fruiting and seeding phenophases were achieved by only 4 species.Swertiaciliata and Prunella entered into fruiting and seeding phase during mid-August in ES microsite only. Veronica cana entered into fruiting phase mid-August in ES microsite and early September in LS microsite, while Buplurum longicaule entered into fruiting in early and mid-September in ES and LS microsites, respectively. B. amplexicaulis entered into senescence in late August, while all species entered into the senescence phase from early to late September in both ES and LS microsites (Figure 2). Arisema propenquim, Aster methodus, Epilobium roylie, Helina elliptica and Thalictrum foliolossum were present only in LS microsite and Aster methodus germinated in July, while rest germinated in June except Epilobium roylei. Flowering started in June in all species except Thalictrum and Aster methodus. Fruiting was absent in Aster methodus and Thalictrum, while Arisema and Helina remained in the fruiting phase for the whole of August. Epilobium royleishowed two distinct vegetative, flowering and fruiting phenophases between May-July and August-September, but senescence was not observed. All species entered into senescence in September, except Thalictrum, which entered into senescence in October (Figure 2). Aster albescens, Gaultheria trichophylla, Persicaria nepalensis, Rumex nepalensis and $S$ wertia auriculatawere present only in LS microsite. Aster albescens, Persicaria and Rumax germinated in June, while Swertia auriculata germinated in July. Aster albescens flowered in July, while Persicaria, Rumax and $S$ wertia auriculata started fruiting in early August and senescence occurred in early September. Early flowering in May was observed in Gaultheria trichophylla, which later entered into a vegetative phase in late May skipping fruiting. It again flowered in early July and fruiting began in early August and entered senescence in midSeptember. 


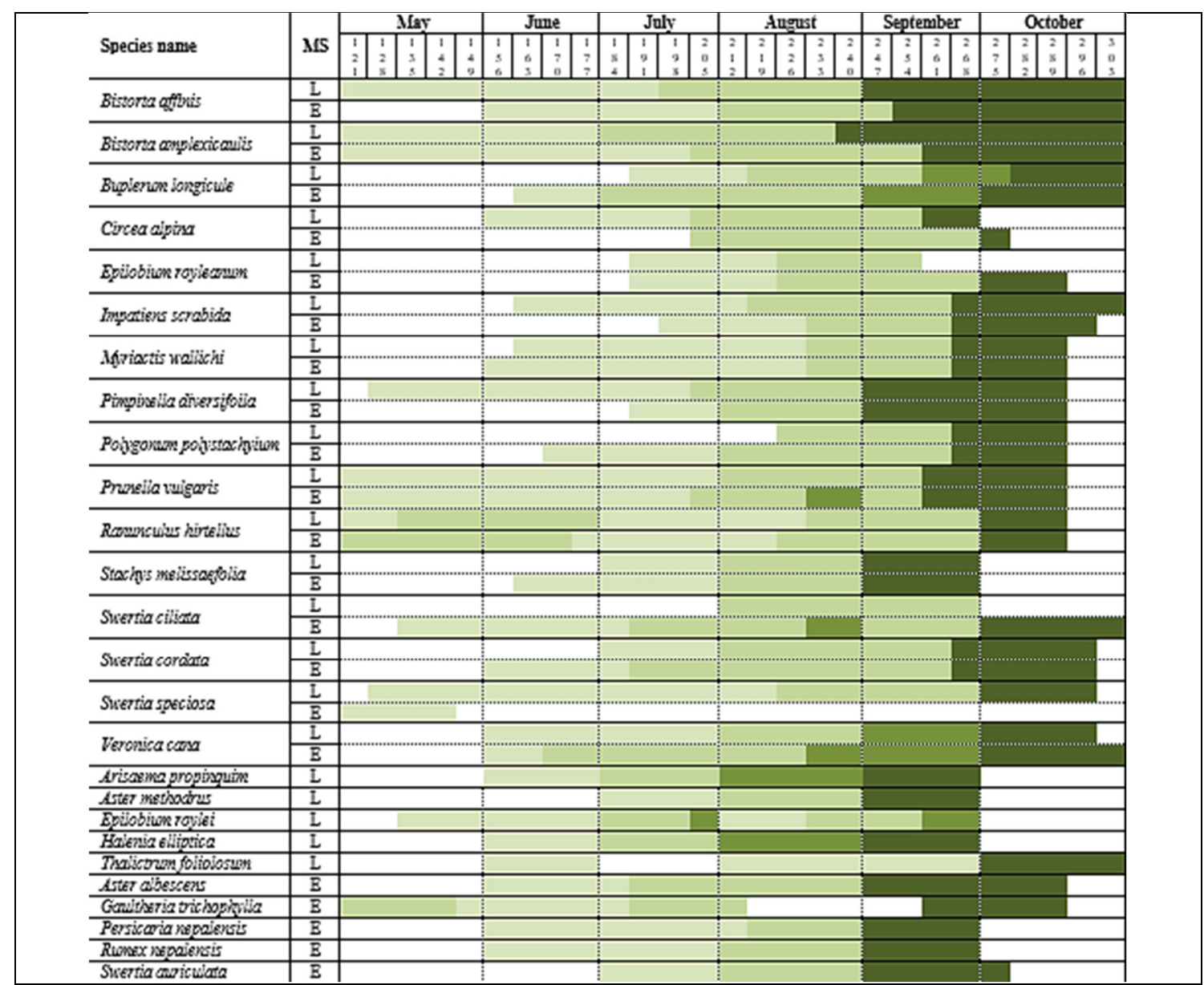

Figure 2. Major phenophases (vegetative, reproductive, fruit/seed development and maturation, and senescence from light olive to dark olive colour, respectively) of different erect leafy growth form species in early and late snowmelt microsites

MS: denotes microsite, L: Late microsite and E: early microsite.

\section{Semi basal growth form}

Among semi basal growth form, 19 species were common in both ES and LS microsites. Anaphalis nepalensis, A. roylie, Anemone rivularis, Arenaria neelgherrensis, Caltha palustris, Carex setosa, Geranium wallichianum, Geum elatum, Kobresia duthiei, Nepeta govaniana, Pedicularis pectinata, Poa annua, Potentilla atrosanguinea and Selinum vaginatum germinated in May, Morina longifolia and Selinum wallichianum in June and Pedicularis hoffmeisteri andAinseliaea aptera in July, while Senecio laetus germinated in August (Figure 3). Anaphalis roylie and Geranium wallichianum germinated in LS microsite only in May, while Arenaria neelgherrensis germinated first in LS microsite. Anemone rivularis flowered first in ES microsite, Carex setosa flowered only in ES microsite, while Caltha palustris, Nepeta govaniana and Arenaria neelgherrensis flowered only in LS microsite during May. Selinum vaginatum flowered together both in ES and LS microsites. Morina longifolia and Selinum wallichianum germinated in ESand LS microsites, respectively only in June, A. roylie and Geranium wallichianum germinated in ES microsite in mid and early June, respectively. Selinum vaginatum reverted to the vegetative phase from the reproductive phase. Geranium and Carex entered in flowering phase during late June, Kobresia and Pedicularis pectinata entered in flowering phase in ES microsite only, while Arenaria neelgherrensis and Caltha palustris entered flowering in ES microsite. Pedicularis hoffmeisteriand Ainseliaea aptera germinated early in July in both ES and LS microsites, while Selinum wallichianum germinated in ES microsite. Anaphalis nepalensis, Geum elatum and Potentilla 
atrosanguinea flowered together in ES and LS microsites in early and mid-July and Ainseliaea aptera entered reproductive phenophase in ES microsite in late July while Poa annua flowered first in LS microsite before ES microsite.

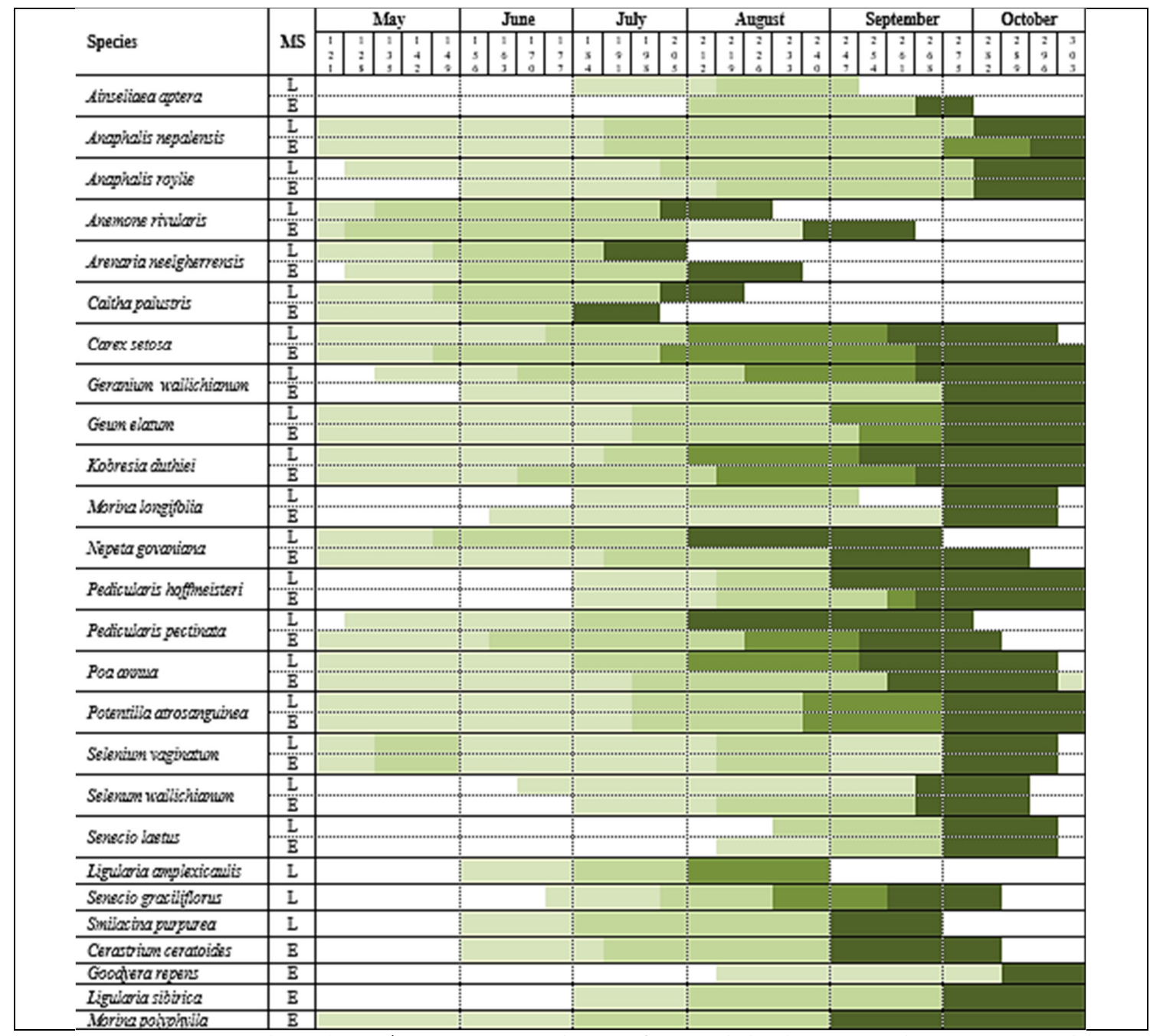

Figure 3. Major phenophases (vegetative, reproductive, fruit/seed development and maturation, and senescence from light olive to dark olive colour, respectively) of different semi basal growth form species in early and late snowmelt microsites

MS: denotes microsite, L: Late microsite and E: early microsite.

Geranium wallichianum and Nepeta govaniana flowered in ES microsite in mid and late July, respectively, while Kobresia, Pedicularis pectinata and A. roylie entered in reproductive phase during early and mid-July. Carex entered in fruiting and seeding phenophase in ES and LS microsites during late July. Anemone rivularis entered senescence in late July in LS microsite, while Arenaria and Caltha entered senescence in ES and LS microsites during early and late July. Senecio laetus germinated in ES and LS microsites in early August and Anemone rivularis reverted to vegetative phase in early August and senescence in late August. Ainsliaeaaptera flowered in LS microsite in early August, while Anaphalis roylie and Selinum wallichianum entered into a reproductive phase during early August in ES microsite, while Ainsliaea aptera, Morina longifolia and Senecio laetus in LS microsite. Pedicularis hoffmeisteri and Selinum vaginatum entered into reproductive phase together in both ES and LS microsites during early August. Kobresia and Potentilla atrosanguinea 
entered into a fruiting phase during early and late August in both ES and LS microsites, Poa annua and Geranium wallichianum in early and mid-August in LS microsite, while Pedicularis pectinata entered in ES microsite during early August. Pedicularis pectinata and Nepeta govaniana entered into senescence in LS microsite, while Anemone rivularis in ES microsite during early and late August. Anaphalis nepalensis and Pedicularis hoffmeisteri entered into a fruiting phase in late September, while Geum elatum entered in both ES and LS microsites during early September. Ainseliaea aptera, Morina longifolia and Nepeta govaniana entered into senescence in ES microsite during late September and Pedicularis pectinata in early September. Poa annua entered senescence in both ES and LS microsites during early September, Carex setosa and Geranium wallichianum in late September, while Pedicularis hoffmeisteri entered senescence first in LS microsite during mid-September and ES microsite in late September and Kobresia in LS and ES microsites in early and late September, respectively. Three species were present only in LS microsite (Ligularia amplexicaulis, Senecio graciliflorus and Smilacina purpurea). Ligularia amplexicaulis and Smilacina germinated in June and entered into a reproductive phase in July, while Ligulariaamplexicaulis entered into a fruiting phase during August, while Smilacina continued into flowering phase and entered senescence during early September, which was not observed in Ligularia amplexicaulis. Seneciogerminated in July, flowered in August, fruiting took place during September and senescenced in October. (Morina polyphylla germinated in May, Cerastrium ceratoides in June, Ligularia sibirica in July and Goodyera repens in August in ES microsite. Morina polyphylla and Cerastrium ceratoides flowered in July and Ligularia sibirica in August. The reproductive phenophase was not observed in Goodyera repens. Morina polyphylla and Cerastrium ceratoides entered senescence during September, while Goodyera repens and Ligularia sibirica entered during October (Figure 3).

\section{Short basal growth form}

Of the total 30 short basal species, 20 species were common in both ES and LS microsites. Sixteen species, Fagaria nubicola, Gentiana argentea, Lysimachia prolifera, Oxygraphis polypetala, Plantago major, Potentilla ancerina, Polygonum delicatula, Polygonum filicaule, Potentilla lineata, Potentilla polyphylla, Primula denticulata, Primula edgeworthii, Sibbaldia cuneata, Synotis alata, Taraxicum officinale, Trachydium royleiand Triplostegia glandulifera were in vegetative phase during May, while germination started in Gentiana argentea as soon as snow melt, so it was not recorded in the growing season, Parnassia nubicola, Synotis alata and Viola biflora in June and Euphorbia stracheyi during July (Figure 4). Fourteen species showed germination during early May, except Triplostegia glandulifera in which germination started during late May. Oxygraphis showed reproductive phase during early May in LS microsite, while it started during mid-May in ES microsite. Trachydium roylei in ES and LS microsites during late May, Fagaria nubicola in ES microsite, while Lysimachia, Plantago major, Primula denticulataand Polygonum filicaule entered into a reproductive phase in LS microsite. Viola biflora germinated during early May in both ES and LS microsites, Synotis alata in LS microsite, while Parnassia nubicola during mid-June in ES microsite only. Potentilla ancerina, Polygonum delicatula and Viola biflora entered into the reproductive phase early during June in both ES and LS microsites. Lysimachia prolifera, Plantago major and Primula denticulata in ES microsite entered the reproductive phase during early June with Fagaria nubicola and Potentilla polyphylla in LS microsite, while Polygonum filicaule and Sibbaldia cuneate in ES microsite entered during late June (Figure 4). Oxygraphis re-entered into a vegetative phase in LS microsite during late June. Fagaria nubicola entered into fruiting phenophase during late June, while Gentiana argentea entered into senescence during early June. Euphorbia stracheyigerminated during mid and late July in ES and LS microsites, while Oxygraphis in ES microsite, Lysimachia prolifera and Primula denticulate re-entered into a vegetative phase in LS microsite during early, mid and late July, respectively. Potentilla lineata flowered during mid-July in both ES and LS microsites, Triplostegia in ES microsite and Sibbaldia in LS microsite entered into the reproductive phase. Fragaria nubicola reverted to flowering from fruiting phase during early July. Plantago major and Trachydium roylei entered into fruiting phase in ES and LS microsites during early and late July, respectively. Synotisalata germinated during mid-August in ES microsite, while Lysimachia prolifera in ES and Trachydium roylei re-entered into the vegetative phase in ES 
and LS microsites during early August from reproductive and fruiting phenophases, respectively. Parnassia nubicola in ES and LS microsites, Triplostegia and Synotisin in ES microsite entered into a reproductive phase during mid and August, while Oxygraphis in ES microsite re-entered during mid-August.

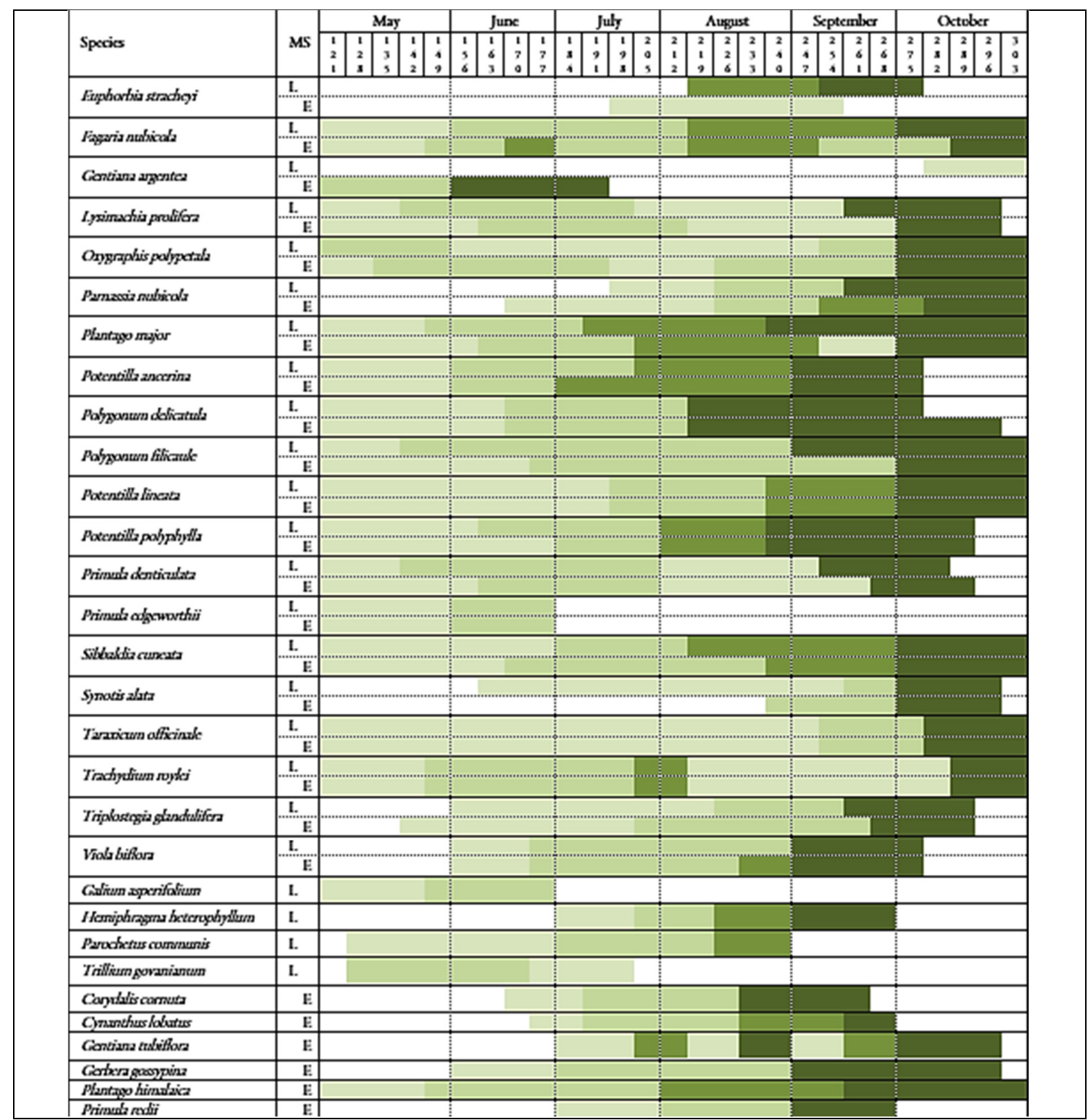

Figure 4. Major phenophases (vegetative, reproductive, fruit/seed development and maturation, and senescence from light olive to dark olive colour, respectively) of different short basal growth form species in early and late snowmelt microsites

MS: denotes microsite, L: Late microsite and E: early microsite.

Fagaria nubicola, Potentilla polyphylla and Potentilla lineata entered into a fruiting phase during early and late August in both ES and LS microsites, while Trachydium roylei entered into fruiting early in LS microsite and in late August in ES microsite. Euphorbia stracheyionly showed fruiting in LS microsite during early August, while Viola in ES microsite during late August. Polygonum delicatula and Potentilla polyphylla entered into senescence in both ES and LS microsites during early and late August. Plantago major re-entered into a vegetative phase from fruiting phase during early September. Taraxicum flowered in both ES and LS 
microsites during early September, while Fagaria nubicola reverted to flowering from fruiting phase during early September in ES microsite. Oxygraphis and Synotis flowered in LS microsite during early and midSeptember. Parnassia nubicola entered into a fruiting phase in ES microsite only during early September. Both Potentilla ancerina and Viola biflora in ES and LS microsites with Euphorbia and Primula denticulata in LS microsite entered into senescence during early September, while Fagaria nubicola, Lysimachia prolifera, Polygonum filicaule, Triplostegia glandulifera and Parnassia nubicola during mid-September. Triplostegia, Primula denticulata and Polygonum filicaule in ES microsite entered into senescence during late September. All the species present in October were in senescence, except Gentiana argentea which was observed in the vegetative phase.Corydalis cornuta, Cynanthus lobatus, Gentiana tubiflora, Gerbera gossypina, Plantago himalaica and Primula redii present only in ES microsite, Plantago himalaica germinated in May and entered into a reproductive phase in late May, fruiting and seeding phases happened from late July and senescent during mid-September. Gerbera gossypina germinated in early June, entered into a reproductive phase in early July and senescence in early September. Corydalis cornuta and Cynanthus lobatus germinated in late June and entered into a reproductive phase in early July. Corydalis cornuta entered into senescence during late August, while Cynanthus lobatus entered into fruiting and seeding phases and senescence in mid-September. Gentiana tubiflora and Primula redii germinated in early July. Primula redii showed only vegetative phase and entered senescence during early September, while Gentiana tubiflora flowered in mid-July and early August. Gentiana tubiflora showed fruiting and seeding phases twice during mid-July and late September and senescence happened in October. Galium asperifolium, Parochetus communis and Trillium govanianum germinated in early May, while Hemiphragma heterophyllum in early July and were present only in LS microsite. Galium asperifolium flowered in late May till June end. Hemiphragma flowered mid-July, fruiting took place midAugust onward and senescence in early September. Parochetus communis flowered in early July and fruiting took place in mid-August, while senescence was not observed. Trillium govanianum flowered early in May and reverted to the vegetative phase in early July (Figure 4).

\section{Other growth forms}

Danthonia cachemyriana (tussock) was present in both ES and LS microsites and germination took place during early and late May in ES and LS microsites, while reproductive phase started during mid-August in both ES and LS microsites and fruiting phase was not observed and senescence started during mid-September (Figure 5). Viburnum glanduliflorum (shrub) germinated in mid-June and remained in vegetative phase till late September. It did not show any other phenophases. Clematis barbellata(climber) and Rubus nepalensis (dwarf shrub) germinated in early June. Clematis showed vegetative (early June and early August), reproductive (midJune and mid-August) and fruiting (mid-July and late August) phases twice. Rubus nepalensis entered into a reproductive phase during early August and entered into senescence during early September skipping fruiting phase (Figure 5).

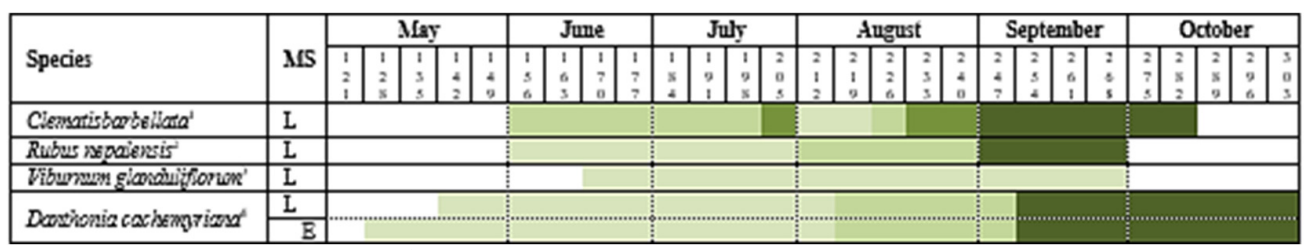

Figure 5. Major phenophases (vegetative, reproductive, fruit/seed development and maturation, and senescence from light olive to dark olive colour, respectively) of climber, dwarf shrub, shrub and tussock growth form species in early and late snowmelt microsites MS: denotes microsite, L: Late microsite and E: early microsite. Climber ${ }^{1}$, Dwarf shrub ${ }^{2}$, Shrub ${ }^{3}$, Tussock ${ }^{4}$ 


\section{Discussion}

The relationship between growth initiation and snowmelt was evident in micro-sites. In general, phenophases were in advanced stages in ES microsite than in LS microsite. Two phenophases (vegetative and reproductive) were observed in the early month of May and June, all four phenophases were observed from July to September with the dominance of vegetative phase in June, reproductive phase in August and senescence phase was observed in September and October. The increase in rainfall $(241.143 .2 \mathrm{~cm}$; Adhikari et al., 2012 and $370.7 \mathrm{~cm}$; GBPIHED) in recent years in the region might be a factor for delay in community senescence. Temperature may be playing an important role as variations in temperatures during growing period have increased compared to past $\left(7.7-12.2^{\circ} \mathrm{C}\right.$ through mercury thermometer at $20 \mathrm{~cm}$ height; Sundriyal et al., 1987 and 2.4-9.9 ${ }^{\circ} \mathrm{C}$ through $\mathrm{HOBO}$ at $150 \mathrm{~cm}$ height; GBPIHED) and difference between maxima and minima have decreased (13.0-23.0 ${ }^{\circ} \mathrm{C}$; Nautiyal et al., 2001 and 9.6-12.6 ${ }^{\circ} \mathrm{C}$; Adhikari et al., 2012), which may help species to remain in different phenophases for longer time period resulting in much overlapping of phenophases. This may be due to warmer temperature in ES microsites which may be encouraging these species to postpone reproductive phenophase for better opportunities.

In the present study, no significant difference was observed within vegetative phenophase in ES and LS microsites for first three $\mathrm{BBCH}$ scale stages across the months and overall, they differ significantly from stage 3 , as most of the species showed transition directly from 0-1 to stage 3 , as a majority of species showed rapid stem elongation/shoot development (main shoot). Although the starting of the vegetative phase in the present study was observed, the end could not be discernible as per the BBCH scale. Therefore, whenever species individuals reached up to $5 \%$ of the next stage, the termination of the previous stage was considered in the quadrat. Similarly, in the reproductive phase, no significant difference was observed between stage 5 and stage 6. Fruiting and seed maturation stages also did not differ significantly across the months while senescence shows an abrupt increase in both ES and LS microsites across the growing season. The timing of different phenophases varies among micro-sites and it was quite similar between Ravanshila and Chandrashila and between Patankudi and Jhabra, while more variability in phenophases was observed in extreme micro-sites, i.e. Ravanshila and Jhabra, can be due to the micro-climatic conditions, which includes environmental conditions (aspect, slope, moisture, soil texture, ambient and soil temperature, rainfall, etc.) and topographical features (gentle, steep, bouldery/rocky, etc.) and anthropogenic traits (grazing, trampling, collection of NTFP) influences the phenophase directly.

Sundriyal et al. (1987) did a comprehensive study on the phenology of alpine plants at Tungnath and reported initial growth of plants during early May to mid-June, but considerable differences in phenological phases of different species. They also reported stability in phase duration for a single species was remarkable despite different locations. Nautiyal et al. (2001) studied the phenology of plants in an alpine pasture of Tungnath. They reported 171 species during their study period (1988-1998) of which 16 species were observed in the flowering phase in May immediately after snowmelt. In these species, flowering buds remain dormant throughout the months of snow cover, with flowering commencing immediately after snowmelt. Gentiana argentea and Oxygraphis polypetala emerged early and were the most dominant species, while Podophyllum hexandrum was scarce and showed vegetative growth as well as flowering. Together, these species illustrate adaptation for survival under harsh climatic conditions. They reported most of the species at the flowering stage from June to late July or early August. In early-growing species, fruiting began as early as the beginning of June, and in other species, peak fruiting occurred during August. Afterward, it declined sharply, and by the beginning of October, only a few species bore fruit. Seed maturation started in the latter half of June. Gradual senescence was observed from July to early September after which it was sudden and massive at a community scale. Bijalwan et al. (2013) studied microclimatic variation influence on the developmental stage of plant species in the alpine region in Dayara, Garhwal Himalaya. They reported phenology of alpine plants is under the direct influence of topographical features and environmental conditions. Out of selected plants, 70\% showed growth initiation during snowmelt during early May except for Parnassia and Bupleurum which 
germinated during late May and June. May and June saw rapid vegetative growth as temperature increased. Major flowering happened between mid-June to early September while fruiting begins early July, peaking in late August. They observed flowering in Geum and Taraxacum during September showing deviation from normal phenology. Negi et al. (1992) studied phenophases in alpine meadows of Bedni-Ali and reported a germination period of two months peaking in late May. Species entered flowering in May and rapidly increased from June while peaked in July. Fruiting started in June and peak fruiting was observed in mid-July and midAugust (70\%). Most of the species bore fruits within a month of fruit formation, senescence gradually started from June showed an abrupt increase in August and peaked between late August and early September.

Comparing Tungnath meadows (Nautiyal et al., 2001; Adhikari et al., 2018) with Bedni-Ali meadows (Negi et al., 1992), in the early years, phenophase progression was similar except they lasted much longer in Tungnath than in Bedni-Ali. The vegetative phase ended by June in Bedni-Ali, while in Tungnath lasted till August (2001) and October (2017). Similarly, flowering and fruiting ended in August in Bedni-Ali (1992) while it was present till September (2001) and October (2017) in Tungnath. Senescence started early in BedniAli (1992) in June, but in Tungnath it started in July (2001; Nautiyal et al., 2001) and May (2017; present study) showing advancement in Tungnath region. The longer phenophase in the Tungnath region compared to other meadows may be due to a higher maximum and minimum temperature and rainfall resulting in a longer growing season. Considering early snowmelt (by March) in past few years it is possible that certain species (Primula edgeworthii, Anemone rivularis, Gentiana spp., Picrorhiza kurroa, Kobressia) have started their growth in early April may be due to high absorbing ability at low soil temperature, might be related to a high level of soluble carbohydrate (Mooney and Billings, 1960) and resulted in early senescence. The species percent in senescence increased sharply from August to September in both studies.

The long vegetative phenophases in the present study could be due to higher precipitation in recent years (Adhikari et al., 2012; GBPNIHED 2017) and less difference in minimum and maximum temperature in recent years as compared with Sundriyal et al. (1987). The precursor to initial plant growth is snowmelt water, which was received during winters in the form of snowfall (39 days; 4 days in December 2016 and 35 days from January to April in 2017), before the onset of the monsoon. The increase in rainfall (241.1 $43.2 \mathrm{~cm}$; Adhikari et al., 2012 and $370.7 \mathrm{~cm}$; GBPIHED) in recent years in the region might be a factor for delay in community senescence. Temperature may be playing an important role as variations in temperatures during growing period have increased compared to past $\left(7.7-12.2^{\circ} \mathrm{C}\right.$ through mercury thermometer at $20 \mathrm{~cm}$ height; Sundriyal et al., 1987 and $2.4-9.9^{\circ} \mathrm{C}$ through $\mathrm{HOBO}$ at $150 \mathrm{~cm}$ height; GBPIHED) and difference between maxima and minima have decreased $\left(13.0-23.0^{\circ} \mathrm{C}\right.$; Nautiyal et al., 2001 and 9.6-12.6 ${ }^{\circ} \mathrm{C}$; Adhikari et al., 2012), which may help species to remain in different phenophases for longer time period resulting in much overlapping of phenophases. A shift of phenophase timing and period for the major of species was observed in general as compared to similar studies conducted in the study area (Nautiyal et al., 2001; Sundriyal et al., 1987).

In the present study an early onset of growth initiation and extended vegetative phenophase was observed, could be due to early snowmelt/soil water thawing leading to early soil moisture availability and ambient temperature, which favoured early growth as suggested by several workers (Ram et al., 1988; Holway and Ward, 1965; Kudo, 1991; Kudo and Suzuki, 1999; Kudo and Hirao, 2006). Flowering and fruiting phenophase has also seen a shift (both advance and lag) in phenophase initiation and duration of the period, in general, have extended compared to other studies (Nautiyal et al., 2001; Sundriyal et al., 1987). Bock (1976), Owen (1976) and Fareed and Caldwell (1975) had also observed the change in flowering due to early snowmelt. The flowering period of plant species is controlled by snow cover (Kudo, 1991, 1992) only in early growing species while late flowering plants flowering period are controlled by photoperiod (Korner, 1999; Keller and Korner, 2003; Giménez et al., 2007) thus determining reproductive success (Thórhallsdóttir, 1998; Hülber et al., 2010). Variation in the phenophase period at spatio-temporal scale due to orography and microenvironmental variables was also observed by Nautiyal et al. (2001). The snowmelt timing with growth initiation and flowering have been observed by Bock (1976), Fareed and Caldwell (1975), and Owen (1976), while ambient temperature during snowmelt strongly favour the growth initiation in alpine plants (Holway 
and Ward 1965; Kudo 1991; Kudo and Suzuki 1999; Kudo and Hirao, 2006). The patterns of phenological events vary at spatio-temporal scale from species to species due to micro-environmental variables as well as orography of the region (Nautiyal et al. 2001) and growth initiation depends on soil water availability due to snowmelt and rise in temperature Ram et al. (1988).

\section{Conclusions}

Although, several factors governing the phenology, among them snowmelt timing is an important key factor. The snowmelt effect can play a major role by warming partially frozen soil and raising temperature above zero kick-starting the root activities, thus affecting the timing of spring phenology. Most of the snow manipulation experiments have been conducted in the temperate or boreal forest with inconsistencies in experimental settings, as these experiments are in-situ, but literature is severely lacking in the Indian Himalayan Region (IHR). The present study sheds some light on phenological behaviour of herb species to snowmelt timing in treeline regions of IHR (early snowmelt, in general, leads to early-onset phenology in species), many other key questions remain unanswered as different ecophysical environments may result with a different response, especially anthesis of herb species across different functional groups (growth forms), which will result in completion and final adjustment between species for the resource (pollinators). Early snowmelt is already identified as a major driver in the onset of spring phenology for herb species at treelines of Himalaya, as comparing our data with past for study site has revealed early-onset and increase in the duration of vegetative and flowering phenophases (based on comparing 13 common herb species).Furthermore, as the temperature increases across the globe, especially in IHR, due to pervasiveness of phenological changes to climate change, it is important to study individuals/functional groups in a different microclimatic environment especially introducing spatial variation and temporal relationship of plants (overlapping of anthesis, etc.), which may evolve. There is a need to study phenological sensitivity of different species especially to spatial variation in a given set of parameters may be different in IHR as elevation range of treeline is wide ( $2000 \mathrm{~m})$, which might result in species showing a wide range of behaviour under similar conditions depending on orography of treelines. Although, several studies have been conducted on phenology and global climate change, the context of snowmelt impact on herb phenology response of a community on spatial landscape level is lacking, especially in context to Indian Himalayan Region.

\section{Authors' Contributions}

The authors read and approved the final manuscript.

\section{Acknowledgements}

Authors are thankful to Director and Dean, Wildlife Institute of India for providing necessary facilities. Thanks, are also due to Prof. S.P. Singh for guidance, MoEF\&CC, New Delhi for funding the project through CHEA, Nainital and Department of Forest, Uttarakahnd state for granting the permission.

\section{Conflict of Interests}

The authors declare that there are no conflicts of interest related to this article. 


\section{References}

Adhikari BS, Rawat GS, Rai ID, Bharti RR, Bhattacharyya, S (2011). Ecological assessment of timberline ecotone in western Himalaya with special reference to climate change and anthropogenic pressures. IV Annual Report, Wildlife Institute of India, Dehradun, India.

Adhikari BS, Kumar R, Singh SP (2018). Early snowmelt impact on herb species composition, diversity and phenology in a western Himalayan treeline ecotone. Tropical Ecology 59(2):365-382.

Anadon-Rosell A, Rixen C, Cherubini P, Wipf S, Hagedorn F, Dawes, MA (2014). Growth and phenology of three dwarf shrub species in a six-year soil warming experiment at the alpine treeline. PLoS One 9(6):100577. https://doi.org/10.1371/journal.pone.0100577

Arft AM, Walker MD, Gurevitch JETA, Alatalo JM, Bret-Harte MS, Dale M, ... Hollister RD (1999). Responses of tundra plants to experimental warming: meta-analysis of the international tundra experiment. Ecological Monographs 69(4):491-511. https://doi.org/10.1890/0012-9615(1999)069[0491:ROTPTE]2.0.CO;2

Aulitzky H (1961) Lufttemperatur und Luftfeuchtigkeit. Mitt Forstl Bundesversuchsanst Mariabrunn 59:105-125.

Baker BB, Moseley RK (2007). Advancing treeline and retreating glaciers: implications for conservation in Yunnan, PR China. Arctic, Antarctic, and Alpine Research 39(2):200-209. https://doi.org/10.1657/15230430(2007)39[200:ATARGI]2.0.CO;2

Barnett TP, Pierce DW, Hidalgo HG, Bonfils C, Santer BD, Das T, ... Cayan DR (2008). Human-induced changes in the hydrology of the western United States. Science 319(5866):1080-1083. https://doi.org/10.1126/science.1152538

Batllori E, Camarero JJ, Ninot JM, Gutiérrez E (2009a). Seedling recruitment, survival and facilitation in alpine Pinus uncinata tree line ecotones Implications and potential responses to climate warming. Global Ecology and Biogeography 18(4):460-472. https://doi.org/10.1111/j.1466-8238.2009.00464.X

Batllori E, Blanco-Moreno JM, Ninot JM, Gutiérrez E, Carrillo E (2009b). Vegetation patterns at the alpine treeline ecotone: the influence of tree cover on abrupt change in species composition of alpine communities. Journal of vegetation science 20(5):814-825. https://doi.org/10.1111/j.1654-1103.2009.01085.X

Bijalwan R, Vats M, Joshi SP (2013). Plant phenological response to microclimatic variations in an alpine zone of Garhwal Himalaya. Journal of Applied and Natural Science 5(1):47-52. https://doi.org/10.31018/jans.v5i1.280

Bock JH (1976). The effects of increased snowpack on the phenology and seed germinability of selected alpine species. Ecological impacts of snowpack augmentation in the San Juan Mountains of Colorado US Department of the Interior, Division of Atmospheric Water Resources Management, Bureau of Reclamation, Denver, Colorado, USA. pp 265-271.

Callaghan TV, Crawford RM, Eronen M, Hofgaard A, Payette S, Rees WG, ... Werkman BR (2002). The dynamics of the tundra-taiga boundary: an overview and suggested coordinated and integrated approach to research. Ambio 3-5.

Camarero JJ, Gutiérrez E (2002). Plant species distribution across two contrasting treeline ecotones in the Spanish Pyrenees. Plant Ecology 162(2):247-257. https://doi.org/10.1023/A:1020367918521

Campioli M, Leblans N, Michelsen A (2012). Twenty-two years of warming, fertilisation and shading of subarctic heath shrubs promote secondary growth and plasticity but not primary growth. PloS One 7(4):34842. https://doi.org/10.1371/journal.pone.0034842

Chapin III FS, Shaver GR (1996). Physiological and growth responses of arctic plants to a field experiment simulating climatic change. Ecology 77(3):822-840.

Chapin III FS, Shaver GR, Giblin AE, Nadelhoffer KJ, Laundre JA (1995). Responses of arctic tundra to experimental and observed changes in climate. Ecology 76(3):694-711. https://doi.org/10.2307/1939337

Chen IC, Hill JK, Ohlemüller R, Roy DB, Thomas CD (2011). Rapid range shifts of species associated with high levels of climate warming. Science 333(6045):1024-1026. https://doi.org/10.1126/science. 1206432

Clow DW (2010). Changes in the timing of snowmelt and streamflow in Colorado: a response to recent warming. Journal of Climate 23(9):2293-2306. https://doi.org/10.1175/2009JCLI2951.1

Cudlín P, Klop M, Tognetti R, Máli F, Alados CL, Bebi P, ... Wielgolaski FE (2017). Drivers of treeline shift in different European mountains. Climate Research 73. https://doi.org/10.3354/cr01465 
Cumming SG, Burton PJ (1996). Phenology-mediated effects of climatic change on some simulated British Columbia forests. Climatic Change 34(2):213-222. https://doi.org/10.1007/BF00224632

Dhar U (2000). Prioritization of conservation sites in the timberline zone of west Himalaya. Setting Biodiversity Conservation Priorities for India 1:193-211.

Doležal J, Šrůtek M (2002). Altitudinal changes in composition and structure of mountain-temperate vegetation: a case study from the Western Carpathians. Plant Ecology 158(2):201-221. https://doi.org/10.1023/A:1015564303206

Dyer JL, Mote TL (2007). Trends in snow ablation over North America. International Journal of Climatology 27(6):739748. https://doi.org/10.1002/joc.1426

Elmendorf SC, Henry GH, Hollister RD, Björk RG, Bjorkman AD, Callaghan TV, ... Fosaa AM (2012). Global assessment of experimental climate warming on tundra vegetation: heterogeneity over space and time. Ecology Letters 15(2):164-175. https://doi.org/10.1111/j.1461-0248.2011.01716.x

Evans BM, Walker DA, Benson CS, Nordstrand EA, Petersen GW (1989). Spatial interrelationships between terrain, snow distribution and vegetation patterns at an arctic foothills site in Alaska. Ecography 12(3):270-278. https://doi.org/10.1111/j.1600-0587.1989.tb00846.x

Eviner VT, Chapin III FS (2003). Functional matrix: a conceptual framework for predicting multiple plant effects on ecosystem processes. Annual Review of Ecology, Evolution and Systematics 34(1):455-485. https://doi.org/10.1146/annurev.ecolsys.34.011802.132342

Fareed M, Caldwell MM (1975). Phenological patterns of two alpine tundra plant populations on Niwot Ridge, Colorado. Northwest Science 49:17-23.

Giménez-Benavides L, Escudero A, Iriondo JM (2007). Reproductive limits of a late-flowering high-mountain Mediterranean plant along an elevational climate gradient. New Phytologist 173(2):367-382. https://doi.org/10.1111/j.1469-8137.2006.01932.x

Gobiet A, Kotlarski S, Beniston M, Heinrich G, Rajczak J, Stoffel M (2014). 21st century climate change in the European Alps - a review. Science of the Total Environment 493:1138-1151. https://doi.org/10.1016/j.scitotenv.2013.07.050

Gorsuch DM, Oberbauer SF (2002). Effects of mid-season frost and elevated growing season temperature on stomatal conductance and specific xylem conductivity of the arctic shrub, Salix pulchra. Tree Physiology 22(14):10271034. https://doi.org/10.1093/treephys/22.14.1027

Gottfried M, Pauli H, Futschik A, Akhalkatsi M, Barančok P, Alonso JLB, ... Krajči J (2012). Continent-wide response of mountain vegetation to climate change. Nature Climate Change 2(2):111.

Grabherr G, Gottfried M, Pauli H (1994). Climate effects on mountain plants. Nature 369(6480):448.

Grace J, Berninger F, Nagy L (2002). Impacts of climate change on the treeline. Annals of Botany 90(4):537-544. https://doi.org/10.1038/369448aO

Grytnes JA, Kapfer J, Jurasinski G, Birks HH, Henriksen H, Klanderud K, ... Birks HJB (2014). Identifying the driving factors behind observed elevational range shifts on European mountains. Global Ecology and Biogeography 23(8):876-884. https://doi.org/10.1111/geb.12170

Hess M, Barralis G, Bleiholder H, Buhr L, Eggers TH, Hack H, Stauss R (1997). Use of the extended BBCH scalegeneral for the descriptions of the growth stages of mono; and dicotyledonous weed species. Weed Research 37(6):433-441. https://doi.org/10.1046/j.1365-3180.1997.d01-70.x

Holway JG, Ward RT (1965). Phenology of alpine plants in northern Colorado. Ecology 46(1-2):73-83.

Hülber K, Winkler M, Grabherr G (2010). Intraseasonal climate and habitat-specific variability controls the flowering phenology of high alpine plant species. Functional Ecology 24(2):245-252. https://doi.org/10.1111/j.13652435.2009.01645.x

Inouye DW, Wielgolaski FE (2003). High altitude climates In: Schwartz, MD (ed) Phenology: an integrative environmental science. Dordrecht: Kluwer Academic Publishers, pp 564.

Inouye DW (2000). The ecological and evolutionary significance of frost in the context of climate change. Ecology Letters 3(5):457-463. https://doi.org/10.1046/j.1461-0248.2000.00165.x

Jones HG, Pomeroy JW, Walker DA, Hoham RW (2001) Snow ecology: an interdisciplinary examination of snowcovered ecosystems. 1st edition Cambridge University Press: Press Syndicate of the University of Cambridge, pp 378. 
Kaarlejärvi E, Baxter R, Hofgaard A, Hytteborn H, Khitun O, Molau U, ... Olofsson J (2012). Effects of warming on shrub abundance and chemistry drive ecosystem-level changes in a forest-tundra ecotone. Ecosystems 15(8):1219-1233. https://doi.org/10.1007/s10021-012-9580-9

Kambo D, Danby RK (2017). Constraints on treeline advance in a warming climate: a test of the reproduction limitation hypothesis. Journal of Plant Ecology 11(3):411-422. https://doi.org/10.1093/jpe/rtx009

Keller F, Körner C (2003). The role of photoperiodism in alpine plant development. Arctic, Antarctic and Alpine Research 35(3):361-368. https://doi.org/10.1657/1523-0430(2003)035[0361:TROPIA]2.0.CO;2

Kimmins JP, Lavender DP (1992). Ecosystem-level changes that may be expected in a changing global climate: A British Columbia perspective. Environmental Toxicology and Chemistry: An International Journal 11(8):1061-1068. https://doi.org/10.1002/etc.5620110803

Körner C (1999). Alpine plants: stressed or adapted? In: Press, M, Scholes, J and Barker, M Physiological Plant Ecology (Eds). 39th Symposium of the British Ecological Society, Cambridge University Press 39:297-311.

Körner C, Basler D (2010). Phenology under global warming. Science 327(5972):1461-1462. https://doi.org/10.1126/science.1186473

Körner C (2012a). Alpine treelines: functional ecology of the global high elevation tree limits. Springer Science \& Business Media.

Körner C (2012b). Treelines will be understood once the functional difference between a tree and a shrub is. Ambio 41(3):197-206. https://doi.org/10.1007/s13280-012-0313-2

Körner C (2016a). Plant adaptation to cold climates. F1000Research 5:2769.

Körner C (2016b). When it gets cold, plant size matters-a comment on treeline. Journal of Vegetation Science 27(1):67. https://doi.org/10.1111/jvs.12366

Körner C, Basler D, Hoch G, Kollas C, Lenz A, Randin CF, Vitasse Y, Zimmermann NE (2016). Where, why and how? Explaining the low-temperature range limits of temperate tree species. Journal of Ecology 104(4):1076-1088. https://doi.org/10.1111/1365-2745.12574

Kudo G (1991). Effects of snow-free period on the phenology of alpine plants inhabiting snow patches. Arctic and alpine research 23(4):436-443.

Kudo G (1992). Performance and phenology of alpine herbs along a snow-melting gradient. Ecological Research 7(3):297304.

Kudo G, Suzuki S (1999). Flowering phenology of alpine plant communities along a gradient of snowmelt timing. Polar Bioscience 12:100-113.

Kudo G, Hirao AS (2006). Habitat-specific responses in the flowering phenology and seed set of alpine plants to climate variation: implications for global-change impacts. Population Ecology 48(1):49-58. https://doi.org/10.1007/s10144-005-0242-Z

Kudo G, Ida TY (2013). Early onset of spring increases the phenological mismatch between plants and pollinators. Ecology 94(10):2311-2320. https://doi.org/10.1890/12-2003.1

Laternser M, Schneebeli M (2003). Long-term snow climate trends of the Swiss Alps (1931-99). International Journal of Climatology 23(7):733-750. https://doi.org/10.1002/joc.912

le Roux PC, Aalto J, Luoto M (2013). Soil moisture's underestimated role in climate change impact modelling in lowenergy systems. Global Change Biology 19(10):2965-2975. https://doi.org/10.1111/gcb.12286

Lenoir J, Gégout JC, Marquet PA, De Ruffray P, Brisse H (2008). A significant upward shift in plant species optimum elevation during the 20th century. Science 320(5884):1768-1771. https://doi.org/10.1126/science.1156831

López-Moreno JI (2005). Recent variations of snowpack depth in the Central Spanish Pyrenees. Arctic, Antarctic and Alpine Research 37(2):253-260. https://doi.org/10.1657/1523-0430(2005)037[0253:RVOSDI]2.0.CO;2

Mayor JR, Sanders NJ, Classen AT, Bardgett RD, Clément JC, Fajardo A, ... Cieraad E (2017). Elevation alters ecosystem properties across temperate treelines globally. Nature 542(7639):91-95. https://doi.org/10.1038/nature21027

Miller-Rushing AJ, Høye TT, Inouye DW, Post E (2010). The effects of phenological mismatches on demography. Philosophical Transactions of the Royal Society. B: Biological Sciences 365(1555):3177-3186. https://doi.org/10.1098/rstb.2010.0148

Mohapatra J (2015). The changing face of the alpine ecosystem in the Himalaya. ENVIS Newsletter on Himalayan Ecology 12(2):9.

Mooney HA, Billings WD (1960). The annual carbohydrate cycle of alpine plants as related to growth. American Journal of Botany 47(7):594-598. https://doi.org/10.1002/j.1537-2197.1960.tb14911.x 
Mote PW, Hamlet AF, Clark MP, Lettenmaier DP (2005). Declining mountain snowpack in western North America. Bulletin of the American Meteorological Society 86(1):39-50. https://doi.org/10.1175/BAMS-86-139

Mote PW, Li S, Lettenmaier DP, Xiao M, Engel R (2018). Dramatic declines in snowpack in the western US. Npj Climate and Atmospheric Science 1(1):2. https://doi.org/10.1038/s41612-018-0012-1

Nautiyal MC, Nautiyal BP, Prakash V (2001). Phenology and growth form distribution in an alpine pasture at Tungnath, Garhwal, Himalaya. Mountain Research and Development 21(2):168-175.

Negi GCS, Rikhari HC, Singh SP (1992). Phenological features in relation to growth forms and biomass accumulation in an alpine meadow of the Central Himalaya. Vegetatio 101(2):161-170.

Odland A, Munkejord HK (2008). Plants as indicators of snow layer duration in southern Norwegian mountains. Ecological Indicators 8(1):57-68. https://doi.org/10.1016/j.ecolind.2006.12.005

Owen HE (1976). Phenological development of herbaceous plants in relation to snowmelt date. Ecological impacts of snowpack augmentation in the San Juan Mountains of Colorado US Dept of the Interior, Division of Atmospheric Water Resources Management, Bureau of Reclamation, Denver, Colorado, USA pp 323-341.

Parmesan C (2006). Ecological and evolutionary responses to recent climate change. Annual Review of Ecology, Evolution, and Systematics 37:637-669. https://doi.org/10.1146/annurev.ecolsys.37.091305.110100

Parmesan C (2007). Influences of species, latitudes and methodologies on estimates of phenological response to global warming. Global Change Biology 13(9):1860-1872. https://doi.org/10.1111/j.1365-2486.2007.01404.X

Pauli H, Gottfried M, Dullinger S, Abdaladze O, Akhalkatsi M, Alonso JLB, ... Ghosn D (2012). Recent plant diversity changes on Europe's mountain summits. Science 336(6079):353-355. Https://doi.org/10.1126/science.1219033

Pauli H, Gottfried M, Reiter K, Klettner C, Grabherr G (2007). Signals of range expansions and contractions of vascular plants in the high Alps: observations (1994-2004) at the GLORIA* master site Schrankogel, Tyrol, Austria. Global Change Biology 13(1):147-156. https://doi.org/10.1111/j.1365-2486.2006.01282.x

Peñuelas J, Ogaya R, Boada M, Jump, AS (2007). Migration, invasion and decline: changes in recruitment and forest structure in a warming-linked shift of European beech forest in Catalonia (NE Spain). Ecography 30(6):829837.

Pomeroy JW, Brun E (2001). Physical properties of snow. In: Jones HG, Pomeroy JW, Walker DA, Hoham RW (Eds). Snow Ecology. Cambridge University Press, Cambridge pp 45-126.

Ram J, Singh SP, Singh JS (1988). Community level phenology of grassland above treeline in central Himalaya, India. Arctic and Alpine Research 20(3):325-332. https://doi.org/10.2307/1551264

Rathcke B, Lacey EP (1985). Phenological patterns of terrestrial plants. Annual Review of Ecology and Systematics 16(1):179-214. https://doi.org/10.1146/annurev.es.16.110185.001143

Schickhoff U, Bobrowski M, Böhner J, Bürzle B, Chaudhary RP, Gerlitz L, ... Schwab N (2015). Do Himalayan treelines respond to recent climate change? An evaluation of sensitivity indicators. Earth System Dynamics 6(1).

Singh SP (2018). Research on Indian Himalayan treeline ecotone: an overview. Tropical Ecology 59(2):163-176.

Smith JG, Sconiers W, Spasojevic MJ, Ashton IW, Suding KN (2012). Phenological changes in alpine plants in response to increased snowpack, temperature, and nitrogen. Arctic, Antarctic, and Alpine Research 44(1):135-142. https://doi.org/10.1657/1938-4246-44.1.135

Steinbauer MJ, Grytnes JA, Jurasinski G, Kulonen A, Lenoir J, Pauli H, ... Wipf S (2018). Accelerated increase in plant species richness on mountain summits is linked to warming. Nature 556(7700):231. https://doi.org/10.1038/s41586-018-0005-6

IPCC (2013). Climate change 2013: the physical science basis. Contribution of Working Group I to the Fifth Assessment Report of the Intergovernmental Panel on Climate Change. Stocker TF, Qin D, Plattner G-K, Tignor M, Allen SK, Boschung J, Nauels A, Xia Y, Bex V, Midgley PM (Eds). Cambridge University Press, Cambridge, United Kingdom and New York, NY, USA, pp 1535.

Sturm W, Willmes K, Orgass B, Hartje W (1997). Do specific attention deficits need specific training? Neuropsychological Rehabilitation $7(2): 81-103$. https://doi.org/10.1080/713755526

Sundriyal RC, Joshi AP, Dhasmana R (1987). Phenology of high-altitude plants at Tungnath in the Garhwal Himalaya. Tropical Ecology 28:289-299.

Thackeray SJ, Sparks TH, Frederiksen M, Burthe S, Bacon PJ, Bell JR, ... Clutton-Brock TIM (2010). Trophic level asynchrony in rates of phenological change for marine, freshwater and terrestrial environments. Global Change Biology 16(12):3304-3313. 
Thórhallsdóttir TE (1998). Flowering phenology in the central highland of Iceland and implications for climatic warming in the Arctic. Oecologia 114(1):43-49. https://doi.org/10.1007/s004420050418

Walker DA, Halfpenny JC, Walker MD, Wessman CA (1993). Long-term studies of snow-vegetation interactions. BioScience 43(5):287-301. https://doi.org/10.2307/1312061

Walther GR (2003). Plants in a warmer world. Perspectives in Plant Ecology, Evolution and Systematics 6(3):169-185. https://doi.org/10.1078/1433-8319-00076

Walther GR, Beibner S, Burga CA (2005). Trends in the upward shift of alpine plants. Journal of Vegetation Science 16(5):541-548.

Wielgolaski FE, Hofgaard A, Holtmeier FK (2017). Sensitivity to environmental change of the treeline ecotone and its associated biodiversity in European mountains. Climate Research 73(1-2):151-166. https://doi.org/10.3354/cr01474

Winkler DE, Butz RJ, Germino MJ, Reinhardt K, Kueppers LM (2018) Snowmelt timing regulates community composition, phenology, and physiological performance of alpine plants. Frontiers in Plant Science 9:1140. https://doi.org/10.3389/fpls.2018.01140

Wipf S, Rixen C (2010). A review of snow manipulation experiments in Arctic and alpine tundra ecosystems. Polar Research 29(1):95-109. https://doi.org/10.3402/polar.v29i1.6054

Wipf S, Stöckli V, Herz K, Rixen C (2013). The oldest monitoring site of the Alps revisited: accelerated increase in plant species richness on Piz Linard summit since 1835. Plant Ecology and Diversity 6(3-4):447-455. https://doi.org/10.1080/17550874.2013.764943

Wookey PA, Parsons AN, Welker JM, Potter JA, Callaghan TV, Lee JA, Press MC (1993). Comparative responses of phenology and reproductive development to simulated environmental change in sub-arctic and high arctic plants. Oikos 67(3):490-502. https://doi.org/10.2307/3545361
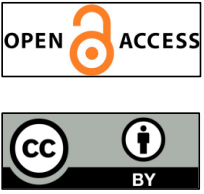

The journal offers free, immediate, and unrestricted access to peer-reviewed research and scholarly work. Users are allowed to read, download, copy, distribute, print, search, or link to the full texts of the articles, or use them for any other lawful purpose, without asking prior permission from the publisher or the author.

License - Articles published in Notulae Scientia Biologicae are Open-Access, distributed under the terms and conditions of the Creative Commons Attribution (CC BY 4.0) License.

(c) Articles by the authors; SHST, Cluj-Napoca, Romania. The journal allows the author(s) to hold the copyright/to retain publishing rights without restriction. 